БАУЭР Владимир Петрович - кандидат технических наук, доктор экономических наук; директор Центра стратегического прогнозирования и планирования Института экономической политики и проблем экономической безопасности Финансового университета при Правительстве РФ (125993, Россия, ГСП-3, г. Москва, Ленинградский пр-кт, 49; bvр09@таil.ru)

\title{
ЭНЕРГЕТИЧЕСКИЕ СОЮЗЫ И ГЕОПОЛИТИКА: ВЗГЛЯД ИЗ РОССИИ
}

Аннотация. В монографии Ш.Г. Шарипова «Энергетические союзы и геополитика» изучаются геополитические сценарии достижения конкурентных преимуществ современными союзами в сфере энергетики. В статье показано, что рассмотренные проблемы вызывают большой научно-практический интерес, оставаясь при этом весьма дискуссионными.

Ключевые слова: энергетика, энергетические пространства, энергетические союзы, глобализация, геополитика, конкурентные преимущества

$\mathrm{B}$ своей монографии «Энергетические союзы и геополитика» [Шарипов 2017в] автор под одной обложкой собрал и раскрыл ключевые проблемы, активно обсуждаемые международным сообществом как непосредственно в области энергетики [Телегина 2015; Бухгольц, Стычински 2017; Бублик и др. 2018], так и в сфере формирования гибридных механизмов сотрудничества мировых энергетических союзов, основанных на принципах энергетической дипломатии и энергетической геополитики [Бушуев и др. 2017; Клименко и др. 2017; Ергин 2017].

Из содержания монографии следует, что ей предшествовала многолетняя и кропотливая работа профессора Ш.Г. Шарипова над решением затронутых проблем [Шарипов 2016а; 2016б; 2016в; 2017а; 2017б; 2018].

Следует согласиться с тем, что автор достаточно объективно исследует процессы формирования энергетических союзов в глобальном геополитическом контексте, особенно с учетом традиций создания союзов на евразийском пространстве, обсуждает нюансы энергетической интеграции как инструмента достижения конкурентных преимуществ и в оптике возможностей геополитики рассматривает энергетические интересы Российской Федерации.

Автор достаточно объективно изучает методологию и инструменты конструирования энергетических пространств, в т.ч. их систематику, закономерности и принципы конструирования, вопросы проектирования энергетических стратегий и геополитики больших пространств, обсуждает геополитический каркас международных политических объединений, управленческие приоритеты в развитии энергетической сферы, энергетическую безопасность в геополитической системе координат, проблемы импортозамещения и инновационных решений в энергетике.

Обсуждая геополитические сценарии достижения конкурентных преимуществ в энергетике, автор выявляет энергетические вызовы на геополитической арене, дает форсайт-прогноз развития международных энергетических рынков, исследует тенденции и перспективы развития отечественной энергетики, находящейся под санкциями Запада, рассматривает кейс осуществимости равноправия Россия в энергодиалоге с Азией и Европой, уточняет геополитику энергетического баланса и в этом же контексте предлагает свое видение процессов формирования европейского, азиатского и ближневосточного векторов внешней энергетической политики Российской Федерации, а также свое виде- 
ние энергетической дипломатии на глобальном геополитическом пространстве будущего миропорядка.

Особенно интересно автор конкретизирует свое видение энергетической стратеги ШОС, реализуемой в контексте глобальной геополитики. В этих целях он разрабатывает форсайт-прогноз развития глобальной нефтегазовой сферы и энергетических институциональных образований ШОС и выдвигает концептуальные основы формирования Энергетического клуба ШОС. В этом же контексте автор исследует проблемы региональной интеграции и реализации энергетических проектов, во-первых, при сопряжении Евразийского экономического союза и Экономического пояса Шелкового пути, во-вторых, при реализации региональной интеграционной политики в формате region to region в Республике Башкортостан и, в-третьих, за счет формирования единого транспортно-энергетического пространства в контексте научных взглядов международного и российского регионализма.

Следует отметить, что большую ценность монографии придают рисунки, выполненные по методу построения логико-смысловых конструкций в виде радиусных (солярных) диаграмм, разработанных профессором B.А. Штейнбергом [Штейнберг 2002, Штейнберг 2015] и использованных профессором В.А. Дергачевым в целях структурирования больших многомерных геополитических пространств [Дергачев 2011].

Вместе с тем следует подчеркнуть, что по ряду исследуемых проблем монография является дискуссионной. В силу ее фундаментальности это видится неизбежным. Объясняется данный феномен также и тем, что в монографии исследуются геополитические процессы в международных и региональных энергетических союзах, которые весьма далеки от своего завершения, причем в условиях неустойчивого межстранового и межрегионального согласия, поскольку они определяют глобальные геополитические тренды развития экономик ведущих стран мира. Автору монографии можно предъявить некоторые общие претензии. Во-первых, это практическое отсутствие таблиц и графиков, иллюстрирующих динамику геополитических процессов в энергетике, во-вторых, стремление автора оставаться в рамках традиционных подходов к трактовкам формирования международных альянсов и хозяйственных союзов.

Высказанные замечания не умаляют большую научную и практическую ценность монографии, которая является одной из первых в мире попыток комплексного рассмотрения заявленной темы исследования.

\section{Список литературы}

Бублик Н.Д., Урманцев У.Р., Ахмеров Э.Р. и др. 2018. Сбалансированное инновационное развитие нефтяных компаний: финансы, производство, исследования: монография. М.: Креативная экономика. 328 с.

Бухгольц Б.М., Стычински 3.А. 2017. Smart Grids - основы и технологии энергосистем будущего. М.: ИД МЭИ. 461 с.

Бушуев В.В., Мастепанов А.М., Первухин В.В., Шафраник Ю.К. 2017. Евразийская энергетическая иивилизащия. К вопросу об «энергии будущего». М.: ИЦ «Энергия». 208 с.

Дергачев В.А. 2011. Геополитическая теория больших многомерных пространств. Издательский проект профессора Дергачева. [Электронное издание на CD + гиперссылки].

Ергин Д. 2017. В поисках энергии: ресурсные войны, новые технологии и будущее энергетики. М.: Альпина Паблишер. 718 с.

Клименко В.В., Терешин А.Г., Микушина О.В. и др. 2017. Перспективы экс- 
порта энергоресурсов из России: социокультурные, экологические и технологические аспекты. М.: ИД «Энергия». 160 с.

Телегина Е.А. 2015. Углеводородная экономика. 2-е изд, испр. и доп. М.: Изд-во ИЦ РГУ нефти и газа им. И.М. Губкина. Ч. 1. 197 с.; Ч. 2. 179 с.

Шарипов Ш.Г. 2016а. Энергетические союзы в геополитическом контексте. - Вестник Башкирского института социальных технологий. № 4(33). С. 19-27.

Шарипов Ш.Г. 2016б. Систематика энергетической геополитики партнерства. - Власть. Т. 24. № 11. С. 197-204.

Шарипов Ш.Г. 2016в. Энергетическое стратегирование в регионе. - Экономика и управление: научно-практический журнал. № 6(134). С. 34-41.

Шарипов Ш.Г. 2017а. Энергетическая безопасность в геоэкономической системе координат. - Вестник Башкирского института социальных технологий. № 1(34). С. 2-28.

Шарипов Ш.Г. 2017б. Энергетический каркас Республики Башкортостан в парадигме «region to region». - Регионология. Т. 25. № 1(98). С. 33-55.

Шарипов Ш.Г. 2017в. Энергетические союзы и геополитика. Уфа: Нефтегазовое дело. 384 с.

Шарипов Ш.Г. 2018. Энергетическое равновесие «азиатского» и «европейского» векторов. - Экономика и управление: научно-практический журнал. № 1(139). С. 9-15.

Штейнберг В.И. 2002. Дидактические многомерные инструменты. Теория, методика, практика. М.: Народное образование; НИИ школьных технологий. 303 c.

Штейнберг В.Э. 2015. Теория и практика дидактической многомерной технологии. М.: Народное образование. 350 с.

BAUER Vladimir Petrovich, Cand.Sci. (Tech.), Dr.Sci. (Econ.); Director of the Center for Strategic Forecasting and Planning, Institute of Economic Policy and Economic Security, Financial University under the Government of the Russian Federation (49 Leningradsky Ave, GSP-3, Moscow, Russia, 125993; bvp09@mail.ru)

\section{ENERGY ALLIANCES AND GEOPOLITICS: VIEW FROM RUSSIA}

Abstract. The paper presents the monograph by Sh.G. Sharipov «Energy Alliances and Geopolitics» which studies geopolitical scenarios for achieving competitive advantages by modern unions in the field of energy. The article shows that the problems discussed are of great scientific and practical interest, while remaining very debatable.

Keywords: energy, energy spaces, energy unions, globalization, geopolitics, competitive advantages 